\title{
Multiple Large Shareholders And Owner-Manager Compensation: Evidence From French Listed Firms
}

Sarra Amdouni, ESSEC Tunis, Tunis, Tunisia

Sabri Boubaker, Champagne School of Management, Groupe ESC Troyes, \& IRG, Université Paris Est, Créteil, France

\begin{abstract}
The objective of this study is to examine the relation between complex ownership structures and managerial compensation. More specifically, we examine the impact of the owner-manager's excess control and the presence of multiple large shareholders $(M L S)$ on the owner-manager's compensation. Using a sample of French publicly listed firms, the results reveal several important points. First, the owner-manager's compensation increases with the owner-manager's excess control. This finding indicates that managers use their power to increase their pay, hence expropriating minority shareholders. Second, the presence of MLS decreases managerial opportunism and prevents owner-managers from diverting corporate resources for their own benefit. Hence, MLS play an important monitoring role.
\end{abstract}

Keywords: Corporate Governance; Excess Control; Multiple Large Shareholders; CEO Compensation; France

\section{INTRODUCTION}

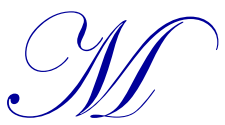

anagerial compensation has recently been a topic of great interest to practitioners and academic researchers (Firth et al., 2010; Gao et al., 2012). Interest in this topic has further escalated after the many financial scandals that erupted in major financial markets around the world (e.g., Enron (2001), Parmalat (2003), Worldcom (2006)), which raised considerable controversy surrounding the level of managerial compensation. These controversies are particularly concerning the existence of a mismatch between manager performance and remuneration (Benson and Davidson, 2010), as well as the unjustified increase in this remuneration (Broye and Moulin, 2010; Chen et al., 2011). To reduce this mismatch, some countries have attempted to regulate managerial compensation by, among other measures, requiring the disclosure of all CEO compensation components. France enacted a law on new economic regulations (NER, 2001) and a financial security law (FSL, 2003). These laws represent a first step toward transparency in CEO compensation. French firms are now required to disclose full information on the compensation of their officers, to reduce their tendency to consume private benefits in the form of salaries at the expense of minority shareholders.

Extraction of private benefits of control is more pronounced in civil law countries featuring weak protection of minority shareholders (La Porta et al., 1998). ${ }^{1}$ In these countries, such as France, concentratedownership firms dominate the economic landscape and agency problems between large and minority shareholders are prevalent. Moreover, these firms exhibit substantial divergence between insider voting rights and cash flow rights, which is maintained through different control-enhancing mechanisms, such as multiple voting shares. A high degree of separation of voting rights and cash-flow rights (i.e., excess control) gives insiders incentive to extract private benefits of control at the expense of minority shareholders (Johnson et al., 2000). Masulis et al. (2009) find a

\footnotetext{
${ }^{1}$ Claessens et al. (2000) and Faccio and Lang (2002) questioned the findings of Berle and Means (1932), who indicated the large widespread dispersed ownership structures. These authors provide evidence that the equity capital of listed firms throughout the world is not widely held outside the United Kingdom and the United States.
} 
positive and statistically significant relation between insiders' excess control and managerial compensation in the Unites States. This result indicates that managers with higher excess control become entrenched, which gives them incentives to divert corporate resources through compensation. The Masulis et al. (2009) results contradict the findings of Barontini and Bozzi (2010), who provide evidence that managerial compensation is negatively related to excess control, implying that managers with higher excess control act in the interest of minority shareholders.

A number of recent studies emphasize the governance role of multiple large shareholders (MLS) in curbing the consumption of private benefits of control, which mitigates agency problems between insiders and minority shareholders (Maury and Pajuste, 2005; Laeven and Levine, 2008). These studies show that the existence of MLS, beyond the largest controlling owner, increases firm value (Maury and Pajuste, 2005; Laeven and Levine, 2008) and reduces the cost of equity (Attig et al., 2008). In addition, the existence of MLS has been shown to significantly affect earnings informativeness (Fan and Wong, 2002), information asymmetry and stock liquidity (Attig et al., 2006), the extent of analyst following (Boubaker and Labegorre, 2008), and the cost of debt (Guedhami and Mishra, 2009; Lin et al., 2011). Maury and Pajuste (2005) and Laeven and Levine (2008) lend support to the hypothesis that the presence of MLS with evenly distributed equity holdings is an effective corporate governance mechanism.

The objective of the present study is to analyze managerial compensation in the presence of a complex ownership structure in France. More specifically, it examines the governance role of MLS on owner-manager's pay $^{2}$. Thus, we begin by focusing on the impact of the owner-manager's excess control on the owner-manager's compensation. Then, we discuss the effect of the existence of one or more controlling shareholders on this compensation.

This work has several implications for the current debate on the determinants of managerial compensation. First, it has the advantage of focusing on the French context. On the one hand, France is characterized by a relatively weak legal system and, thus, a low investor protection environment, which gives rise to expropriation of minority shareholders (La Porta et al., 1999). Typically, French listed firms have a concentrated ownership structure and are controlled through various control-enhancing mechanisms, such as dual-class shares and pyramidal structures. These mechanisms allow the ultimate owners to control their firms while holding only a small fraction of the cash flow rights (Faccio and Lang, 2002; Boubaker and Labégorre, 2008). The separation of ownership and control may result in severe agency conflicts between large and minority shareholders, which enhances the possibility of extracting private benefits of control. On the other hand, the present study is among the first to examine the impact of the owner-manager's excess control on the owner-manager's compensation in France.

Second, to the best of our knowledge, this paper is the first to investigate the impact of MLS on managerial compensation. Previous studies have shown that ownership structure is an important determinant of managerial compensation by focusing on the role of dominant shareholders. Large shareholders are able to closely monitor managers to curb their opportunistic behavior and to reduce their compensation. This argument implies the existence of a negative relation between the presence of more than one large shareholder and owner-manager compensation (Goldberg and Idson, 1995; Conyon and He, 2011), whereas other researchers preclude the existence of such a relationship (Su et al., 2011). The role of large shareholders is similar to the role of institutional investors in reducing excessive CEO compensation (Hartzell and Starks, 2003). Given that institutional investors are mainly interested in performance, one could expect a positive effect from these investors on the sensitivity of compensation to performance (Clay, 2000). The link between compensation and the presence of other types of shareholders is also investigated in the literature. The presence of financial institutions is shown to have a negative impact on compensation, while the presence of families has a positive impact (Amoako-Adu and Smith, 2011).

The remainder of this paper proceeds as follows. Section 2 develops the hypotheses. Section 3 describes sample selection, data sources, and the adopted methodology. Section 4 presents the results. Section 5 describes our conclusions.

\footnotetext{
${ }^{2}$ The terms CEO and owner-managers are used interchangeably in the text.
} 


\section{HYPOTHESES}

\subsection{Effect Of Excess Control On Owner-Manager Compensation}

Excess control by an owner-manager reflects the degree of separation between owner-manager control and cash flow rights. Control-enhancing mechanisms (e.g., pyramiding and dual-class shares) create such separation by allowing the largest controlling shareholders to control their firms while having only a small fraction of cash flow rights (Bebchuk et al., 2000). These mechanisms reinforce and entrench the power of the owner-manager, which provides the owner-manager with strong incentives to extract private benefits of control at the expense of minority shareholders (Grossman and Hart, 1988; Claessens et al., 2002). In this vein, Claessens et al. (2002) and Boubaker (2007), among others, show that the greater the separation between voting rights and cash flow rights, the lower are the incentives for the largest controlling shareholder to run firms properly and the stronger are the incentives to consume private benefits of control (e.g., perks, perquisites, excessive compensation, etc.).

However, the effect of excess control on managerial compensation remains a matter of debate. Previous studies have shown that the separation between control and cash flow rights of the controlling shareholder may have a positive (Masulis et al., 2009) or a negative (Barontini and Bozzi, 2010) effect on managerial compensation. The positive effect may be attributed to the ability of entrenched owner-managers to shift their firm's pay decisions toward higher compensation. Nevertheless, the negative effect may be explained by owner-manager concern about their reputation when there is substantial excess control. Thus, they prefer to improve firm performance and to set fair compensation for themselves.

In France, concentrated-ownership firms dominate the economic landscape. They are often run by members of controlling families, whose voting rights often exceed their cash flow rights (Faccio et al., 2001; Boubaker, 2007; Boubaker and Labégorre, 2008). Thus, French listed firms are typically vulnerable to severe agency conflicts between their owner-managers and minority shareholders. Accordingly, we expect that entrenched owner-managers of these firms have the incentives and power to consume private benefits of control by increasing their compensation (Masulis et al., 2009). Hence, we formulate the following hypothesis:

Hypothesis 1: Owner-manager compensation increases with the separation of voting rights and cash-flow rights of the owner-manager.

\subsection{Effect Of MLS On Owner-Manager Compensation}

The corporate governance literature offers two theoretical views on the role of MLS in corporate governance. According to one view, MLS may have incentive to expropriate minority shareholders. Zwiebel (1995) argues that MLS may collude with other shareholders to extract private benefits of control. Kahn and Winton (1998) argue that large shareholders may adopt opportunistic behavior by preferring to trade on private information rather than curbing the consumption of private benefits by corporate insiders.

The second view is based on the idea that MLS have the incentive (substantial cash flow rights) and power (substantial voting rights) to monitor the owner-manager (Bennedsen and Wolfenzon, 2000; Bloch and Hege, 2003). Laeven and Levine (2008) find that more than $40 \%$ of the European firms in their sample have more than one large shareholder holding at least $10 \%$ of voting rights. These authors provide evidence that MLS play an effective governance role in curbing misuse of corporate resources, which results in higher firm valuations. In the same vein, Maury and Pajuste (2005) show that the presence of MLS mitigates expropriation by the controlling owner, especially when MLS hold evenly distributed voting rights, which increases firm value. According to Bloch and Hege (2003), the presence of two large shareholders reduces the possibility of diversion of corporate resources, as these shareholders prefer to compete for corporate control to attract minority shareholders rather than extracting private benefits of control. Faccio et al. (2001) find that the presence of MLS is associated with lower expropriation by controlling owners, which results in higher dividend payouts in European firms. Bennedsen and Wolfenzon (2000) and Pagano and Röell (1998) argue that MLS can play an important governance role in mitigating agency problems between the controlling owner and minority shareholders. Moreover, results in Attig et al. (2011) indicate that the presence of MLS improves internal governance, resulting in higher value for firm cash holdings. 
We expect that the presence of MLS, beyond the largest controlling owner, has an impact on managerial compensation. As mentioned above, a growing number of theoretical and empirical studies show that MLS are able to prevent the owner-manager from adopting opportunistic behavior that leads to diversion of corporate resources (e.g., Bloch and Hege, 2003; Attig et al., 2011; Boubaker and Sami, 2011). Hence, we draw the following hypothesis:

Hypothesis 2: Owner-manager compensation decreases with the presence of MLS.

\section{METHODOLOGY}

This section describes the sample selection procedure, data sources, empirical model and the variables used in the analysis.

\subsection{Sample Selection And Data Sources}

The initial sample includes all French listed firms available in the Worldscope database over the period 2004-2007. First, we exclude financial firms (SIC codes 6000-6999) and firms with missing financial, ownership, or compensation data. Further, we discard firms that experienced a departure of a CEO (succession, retirement, dismissal, and death) during the sample period. We are left with 459 non-financial firms with 1,476 firm-year observations over the period 2004-2007.

Data on CEO compensation, ownership, and board characteristics are gathered from firm annual reports available from the websites of the AMF (Autorité des Marchés Financiers). ${ }^{3}$ Financial data are gathered from the Worldscope database. Financial variables are winsorized at the 1\% and $99 \%$ levels to mitigate the effects of outliers on the results. Table 2 presents descriptive statistics of all variables used in this study.

\subsection{Model And Measurement Of Variables}

\subsubsection{Model Specification}

To examine the effect of owner-manager excess control and relative power on owner-manager compensation, we consider the following model:

CeoComp $_{i, t}=\beta_{0}+\beta_{1}$ ExControl $_{i, t}+\beta_{2}$ MLSD $_{i, t}+\beta_{3}$ BoardSize $_{i, t}+\beta_{4}$ Duality $_{i, t}+\beta_{5}$ IndDir $_{i, t}+\beta_{6}$ CompCom $_{i, t}$ $+\beta_{7}$ CeoAge $_{i, t}+\beta_{8}$ CeoTen $_{i, t}+\beta_{9}$ CeoFon $_{i, t}+\beta_{10}$ FirmSize $_{i, t}+\beta_{11}$ ROA $_{i, t}+\beta_{\text {Industry Dummies }}+$ Year Dummies $+\varepsilon_{i, t}$

which we estimate using a pooled ordinary least squares regression with industry and year fixed. The t-statistics are calculated using heteroskedasticity-robust standard errors that cluster at the firm level.

\subsubsection{CEO Compensation}

We use two measures of CEO compensation (CеoComp), namely total CEO compensation and variable CEO compensation (Core et al., 1999; Chalmers et al., 2006). Total compensation of the CEO (TotCeoComp) includes all components of compensation, that is, fixed, bonus, stock options, and granted stocks. The variable portion of compensation excludes the fixed portion.

\subsubsection{Ownership Variables}

The owner-manager's excess control is a proxy for the degree of separation of cash flow rights and voting rights. We follow the approach of Claessens et al. (2000, 2002) and Faccio and Lang (2002) to compute, for each concentrated ownership firm in our sample, the ultimate cash flow and control rights of its owner-manager. ${ }^{4}$ The

\footnotetext{
${ }^{3}$ Autorité des Marchés Financiers Financiers (AMF) is the French equivalent of the US Securities and Exchange Commission (SEC).

${ }^{4}$ See, La Porta et al. (1999), Claessens et al. (2000, 2002), and Faccio and Lang (2002).
} 
excess control of the owner-manager "ExControl" is the difference between the owner-manager's ultimate cash flow and ultimate control rights, all divided by the owner-manager's ultimate control rights. We consider that a firm has an owner-manager when this individual holds directly and indirectly at least $10 \%$ of the voting rights of the firm. 5,6 $M L S D$ is a dummy variable that is set to 1 if the firm has at least one external blockholder that controls, directly or indirectly, at least $10 \%$ of the voting rights of the firm. ${ }^{7}$

\subsubsection{Control Variables}

Board size (BoardSize): The board of directors plays an important role in monitoring managers. However, as the size of the board increases, the actions of managers become more difficult to control, which allows managers to benefit from larger compensation. Several studies conclude that managerial compensation is higher when boards are large (Core et al., 1999; Ozkan, 2007). Thus, we include in our regressions BoardSize, which equals the natural logarithm of the number of directors on the board.

CEO duality (Duality): Board effectiveness depends on separation of the CEO and chair of the board positions. Such separation prevents the CEO from imposing excessive and unfair compensation contracts (Boyd, 1994; Cyert et al., 2002). To proxy for CEO duality, we consider a dummy variable Duality, which equals 1 if the executive holds both the positions of CEO and chair of the board, zero otherwise.

Board independence (IndDir): Independent directors are able to monitor CEOs and to influence their compensation decisions, which may result in less excessive CEO compensation (Lambert el al., 1993; Boyd, 1994; Core et al., 1999; and Coakley and Iliopoulou, 2006). We use the variable IndDir, which equals the proportion of independent directors on the board, that is, the number of independent directors divided by the total number of directors on the board.

Compensation committee (CompCom): Studies show that compensation committees are effective at ensuring credibility when setting executive pay (Conyon, 1997). Thus, we include the dummy variable CompCom, which takes the value 1 if the firm has a compensation committee, zero otherwise.

CEO age (CeoAge): Greater CEO experience indicates a higher ability to manage the firm and, thus, higher compensation. Hence, we expect a positive relation between CEO age and CEO compensation ( $\mathrm{Li}$ et al., 2007). However, Croci et al. (2012) find that older managers are more risk averse. The variable CeoAge is the natural logarithm of the CEO's age, in years.

CEO tenure (CeoTen): The longer the CEO tenure, the higher is the CEO's managerial power and ability to command higher compensation (Cyert et al., 2002). Thus, we expect a positive relation between CEO tenure and compensation (Deckop, 1988; Allgood et al., 2012). CEO tenure is measured by the natural logarithm of the number of years the CEO has been in the CEO position.

CEO Founder (CeoFon): The intrinsic motivation of founding managers reduces their need for incentive compensation (Murdock, 2002; Benadou and Tirole, 2003). Therefore, they are expected to receive lower compensation (Gomez-Mejia et al., 2001; 2003). We include in our model a binary variable that takes the value of 1 if the current CEO is the founder of the firm or a member of the founding family, zero otherwise.

Return on assets (ROA): Studies show that firm performance is an important determinant of managerial compensation, since good managerial performance results in higher executive compensation (Buck et al., 2008). To proxy for firm performance, we use $R O A$, which equals the ratio of earnings before interest and taxes to total assets. We expect a positive relation between this variable and CEO compensation.

\footnotetext{
${ }^{5}$ The choice of this threshold is motivated by previous studies such as La Porta et al. (1999), Faccio and Lang (2002) and Claessens et al. (2000, 2002).

${ }^{6}$ If a firm does not have a shareholder that holds directly at least $10 \%$ of the voting rights, it is considered as widely held.

${ }^{7}$ Our results are robust to the use of the lagged and industry-average ownership variables, suggesting that our conclusions are not affected by potential reverse causality.
} 
Firm size (FirmSize): Prior studies provide evidence of a positive relation between firm size and managerial compensation (Murphy, 1999; Elston and Goldberg, 2003; Murphy and Sandino, 2010). The size of the firm, FirmSize, is measured by the natural logarithm of total assets.

\section{DESCRIPTIVE STATISTICS AND CORRELATIONS}

Table 2 provides descriptive statistics (mean, standard deviation, 5th percentile, 25th percentile, median, 75th percentile, and 95th percentile) for the variables used in the analysis. The average total (variable) CEO compensation is $311,458 €(265,667 €)$. It seems that managerial average pay is less than that perceived by managers in the Anglo-Saxon countries such as the United States. This may be due to the larger size of US listed firms compared to that of French listed firms.

Table 2 also shows that the average CEO age in our sample is 52. CEO tenure in the firm is, on average, six years. Moreover, we find that, on average, only $27.40 \%$ of the members of boards of directors are independent, indicating that the independence of French boards remains relatively limited despite the requirements of codes of best corporate governance. Indeed, if a board is dominated by internal directors, it is less able to impair the ability of the controlling owners to extract private benefits, which results, among other practices, in higher CEO compensation. Firms with powerful CEOs that accumulate both the titles of CEO and Chair of the Board are also less effective at setting executive pay. Table 2 shows that, on average, $69.24 \%$ of sample firms do not separate the positions of CEO and Chair of the Board. A concentration of power in the hands of the manager strengthens the manager's position, which may hinder the mission of independent directors to work in the interests of the firm.

In addition, we find that only $43.86 \%$ of our sample firms have a compensation committee, which affects their ability to curb extraction of private benefits through higher CEO compensation. This low percentage reflects certain subjectivity in fixing the compensation of French CEOs.

Table 3 provides Pearson correlation coefficients of variables used in the analysis. This correlation matrix shows that the coefficients between the variables are not exceptionally high. Moreover, the variance inflation factors (mean is equal to 1.62) indicate that multicollinearity is not a serious concern.

\section{REGRESSION RESULTS}

Table 4 provides regression results of the relation between owner-manager excess control and the presence of MLS, on the one hand, and total CEO compensation (Column 1) and variable CEO compensation (Column 2), on the other. The R-squared ranges between $26.23 \%$ and $47.63 \%$, which indicates that the set of independent variables is relevant in explaining total and variable CEO compensation.

The results in Table 4 (Column 2) show that the coefficient on "ExControl" is positive and statistically significant at the 5\% level, implying that the variable part of CEO compensation increases with the excess control of the owner-manager. This finding supports the entrenchment effect argument (Claessens et al., 2002; Masulis et al., 2009). CEOs with a higher degree of separation of ownership and control have incentive to consume private benefits of control by increasing their variable compensation. The coefficient on "ExControl" is not statistically significant when the dependent variable is TotCeoComp (Column 1).

Furthermore, Table 4 (Column 2) suggests that the relative power of MLS "MLSD" affects negatively the variable part of CEO compensation. (The coefficient is statistically significant at the 5\% level). This result indicates that MLS play an effective monitoring role that reduces extraction of private benefits of control by owner-managers. MLS prevent owner-managers from extracting higher salaries. Thus, their presence is an effective corporate governance mechanism in France.

As for control variables, Table 4 shows that the existence of a compensation committee, CompCom, is positively and significantly associated with CEO total compensation. This result indicates that compensation committees do not play a disciplinary role that makes them effective in reducing executive pay. These results can be explained by CEOs' ability to shift the balance of power away from these committees, allowing them to impose their preferences for higher compensation. 
The results in Table 4 also provide evidence that board independence, IndDir, is positively and significantly related to the variable part of CEO pay. This result may be explained by the fact that the ownermanagers may build close relationships with independent directors, reducing their monitoring capacity. Board size, BoardSize, has a positive and statistically significant effect on the variable part of CEO pay. Indeed, when board size increases, directors are less able to effectively monitor CEO behavior. As a result of board inefficacy, CEOs increase their variable compensation in a way so as to consume private benefits that do not accrue to minority shareholders. CEO tenure, CeoTen, is positively and significantly related to CEO total compensation. CEO compensation, both total and variable, is found to increase with firm size, FirmSize, substantiating the claim that CEO compensation is higher in large firms.

\section{CONCLUSION}

The objective of this study is to investigate the impact of CEO control over their own compensation. The empirical results reveal that entrenched CEOs have the incentives and power to increase their own compensation. More specifically, we find that the higher the degree of separation of the owner-manager's ownership and control, the higher is the owner-manager's compensation. In addition, we provide evidence that the presence of MLS prevent the controlling owner-manager from diverting corporate resources at the expense of minority shareholders. An interesting research avenue is to examine the impact of external governance mechanisms on the relation between ownership structure and managerial compensation.

\section{AUTHOR INFORMATION}

Sabri Boubaker is Associate Professor of Finance at Champagne School of Management (Groupe ESC Troyes, France) and Research Fellow at the Institut de Recherche en Gestion (University of Paris Est). He holds a Ph.D. in Finance from University of Paris Est (2006) and a HDR degree (Habilitation for Supervising Doctoral Research) in 2010 from the same university. He has recently published several academic papers in international refereed journals including Journal of Banking and Finance, Journal of Applied Business Research, International Review of Financial Analysis, Economic Modeling, Review of Accounting and Finance, Review of Quantitative Accounting and Finance, Journal of Management and Governance, Multinational Finance Journal, Global Finance Journal, International Journal of Business, North American Journal of Economics and Finance, and Journal of International Financial Markets, Institutions and Money. Email: sabri.boubaker@get-mail.fr

Sarra Amdouni is Assistant Professor in Accounting and Finance at ESSEC Tunis (Tunisia). She has a M.Phil in Finance (2007) and a PhD in Management from University of Tunis (2015). Her research interests include corporate governance, board of directors and managerial compensation.

Email: sarra.amdouni@ essec.rnu.tn

\section{REFERENCES}

Allgood, S. Farrell, K, A. and Kamal, R. (2012). Do boards know when they hire a CEO that is a good match? Evidence from initial compensation. Journal of Corporate Finance, 18 (5) 1051-1064.

Amoako-Adu, B. Baulkaran,V. and Smith, B. F. (2011). Executive compensation in firms with concentrated control: The impact of dual class structure and family management. Journal of Corporate Finance, 17 (5) 1580 1594.

Attig, N. El Ghoul, S. Guedhami, O. and Rizeanu, S. (2011). The governance role of multiple large shareholders: Evidence from the valuations of cash holdings. Journal of Management and Governance, 17(1) 1-33.

Attig, N. Fong, W. M. Gadhoum, Y. and Lang, L.H.P. (2006).Effects of large shareholding on information asymmetry and stock liquidity. Journal of Banking and Finance, 30 (10) 2875-2892.

Attig, N. Guedhami, O. and Mishra, D. (2008). Multiple large shareholders, control contests, and implied cost of equity. Journal of Corporate Finance, 14(5) 721-737.

Barontini, R. and Bozzi, S. (2010). CEO compensation and performance in family firms. Working paper.

Bebchuk, L. A. Kraakman, R. and Triantis, G. (2000). Stock pyramids, cross-ownership, and dual class equity: The creation and agency costs of separation control from cash flow rights, in: Morck, R.K. (Eds.). Concentrated Corporate Ownership, University of Chicago Press, Chicago, 295-318. 
Benabou, R. and Tirole, J. (2003). Intrinsic and extrinsic motivation. Review of Economic Studies, 70 (244) 489502 .

Bennedsen, M. and Wolfenzon, D. (2000). The balance of power in closely held corporations. Journal of Financial Economics, 58 (1) 113-139.

Benson, B. W. and Davidson, W. N. (2010). The relation between stakeholder management, firm value and CEO compensation: A test of enlightened value maximization. Financial Management, 39 (3) 929-964.

Berle, A. A. and Means, G. C. (1932).The modern corporation and private property. Macmillan, New York.

Bloch, F. and Hege, U. (2003). Multiple shareholder and control contests., working paper.

Boubaker, S. and Sami, H. (2011). Multiple large shareholders and earnings informativeness. Review of Accounting and Finance, 10 (3) 246-266.

Boubaker, S. (2007). Ownership-control discrepancy and firm value: Evidence from France. Multinational Finance Journal, 11 (3-4) 211-252.

Boubaker, S. and Labégorre, F. (2008). Ownership structure, corporate governance and analyst following: A study of French listed firms. Journal of Banking and Finance, 32 (6) 961-976.

Boyd, B. K. (1994). Board control and CEO compensation. Strategic Management Journal, 15 (5) 335-344.

Broye, G. and Moulin, Y. (2010). Rémunération des dirigeants et gouvernance des entreprises: cas des entreprises françaises cotées. Finance Contrôle Stratégie, 13 (1) 67-98.

Buck, T. Liu, X. and Skovoroda, R. (2008). Top executive pay and firm performance in china. Journal of International Business Studies, 39 (5) 833-850.

Chalmers, K. Koh, P. S. and Stapledon, G. (2006). The determinants of CEO compensation: Rent extraction or labor demand. British Accounting Review, 38 (3) 259-275.

Chen, J. Ezzamel, M. and Cai, Z. (2011). Managerial power theory, tournament theory, and executive pay in China. Journal of Corporate Finance, 17 (4) 1176-1199.

Claessens, S. Djankov, S. Fan J. and Lang, L. H. P. (2002). Disentangling the incentive and entrenchment effects of large shareholdings. The Journal of Finance, 57 (6) 2741-2771.

Claessens, S. Djankov, S. Fan, J. and Lang L. H. P. (2000). The separation of ownership and control in east Asian corporations. Journal of Financial Economics, 58 (1-2) 81-112.

Clay, D. (2000). The effects of institutional investment on CEO compensation. working paper. University of Chicago. Chicago.

Coakley, J. and Iliopoulou, S. (2006). Bidder CEO and other executive compensation in UK M\&As. European Financial Management, 12 (4) 609-663.

Conyon, M. J. and He, L. (2011). Executive compensation and corporate governance in China. Journal of Corporate Finance, 17(4) 1158-1175.

Conyon, M. J. (1997). Corporate governance and executive compensation. International Journal of Industrial Organization, 15(4) 493-509.

Core, E. J. Holthausen, R. W. and Larcker, D. F. (1999). Corporate governance, chief executive officer compensation and firm performance. Journal of Financial Economics, 51(3) 371-406.

Croci, E. Gonenc H. and Ozkan N. (2012). CEO compensation, family control and institutional investors in continental Europe. Journal of Banking and Finance, 36 (12) 3318-3335.

Cyert, R. Kang, S. and Kumar, P. (2002). Corporate governance, takeovers and top management compensation: Theory and evidence. Management Science, 48 (4) 453-469.

Deckop, J. (1988). Determinants of chief executive officer compensation. Industrial and Labour Relations Review, 41 (2) $215-226$.

Elston, J. A. and Goldberg, L. G. (2003). Executive compensation and agency costs in Germany. Journal of Banking and Finance, 27 (7) 1391-1410.

Faccio, M. and Lang, L. H. P. (2002). The ultimate ownership of Western European corporations. Journal of Financial Economics, 65 (3) 365-395.

Faccio, M. Lang, L. H. P. and Young, L. (2001) .Dividends and expropriation. American Economic Review, 91 (1) 54-78.

Fan, J.P.H. and Wong, T.J. (2002). Corporate ownership structure and the informativeness of accounting earnings in East Asia. Journal of Accounting and Economics, 33 (3) 401-425.

Firth, M. Leung, T. Y. and Rui, O, M. (2010). Justifying top management pay in a transitional economy. Journal of Empirical Finance, 17 (5) 852-866. 
Gao, H. Harford, J. and Li, K. (2012). CEO pay cuts and forced turnover: their causes and consequences. Journal of Corporate Finance, 18 (2) 291-310.

Goldberg, L. G. and Idson, T. L. (1995). Executive compensation and agency effects. The Financial Review, 30 (2) 313-335.

Gomez-Mejia, L. Larraza-Kintana, M. and Makri, M. (2003). The determinants of executive compensation in family controlled public corporations. Academy of Management Journal, 46 (2) 226-237.

Gomez-Mejia, L. Nunez-Nickel, M. and Gutierrez, I. (2001). The role of family ties in agency contracts. Academy of Management Journal, 44 (1) 81-95.

Grossman, S. J. and Hart, O. D. (1988). One share-one vote and the market for corporate control. Journal of Financial Economics, 20 (1-2) 175-202.

Guedhami, O. and Mishra, D. (2009). Excess control, corporate governance, and implied cost of equity: International evidence. Financial Review, 44 (4) 489-524.

Hartzell, J. and Starks, L. (2003). Institutional investor and executive compensation. The Journal of Finance, 58 (6) 2351-2374.

Johnson, S. La Porta, R. Lopez-de-Silanes, F. and Shleifer, A. (2000). Tunneling. American Economic Review, 90 (2) $22-27$.

Kahn, C., and Winton, A. (1998). Ownership structure, speculation, and shareholder intervention. The Journal of Finance, 53 (1) 99-129.

La Porta, R. Lopez-De-Silanes, F. Shleifer, A. et Vishny, R. (1998). Law and finance. Journal of Political Economy, 106 (6) 1113-1155.

La Porta, R. Lopez-De-Silanes, F. and Shleifer, A. (1999). Corporate ownership around the world. The Journal of Finance, 54 (2) 471-517.

Laeven, L. and Levine, R. (2008). Complex ownership structures and corporate valuations. Review of Financial Studies, 21 (2) 579-604.

Lambert, R. Larcker, D. and Weigelt, K. (1993). The structure of organizational incentives. Administrative Science Quarterly, 38 (3) 438-461.

Li, D. Fariborz, M. Pascal, N. and Liwen, T. (2007). Corporate governance or globalization: what determines CEO compensation in China?. Research in International Business and Finance, 21 (1) 32-49.

Lin, C. Ma, Y. Malatesta, P. and Xuan, Y. (2011). Ownership structure and the cost of corporate borrowing. Journal of Financial Economics, 100 (1) 1-23.

Masulis, R. W. Wang, C. and Xie, F. (2009). Agency problems at dual-class companies. The Journal of Finance, 57 (4) $1697-1727$.

Maury, C. B. and Pajuste, A. (2005). Multiple large shareholders and firm value. Journal of Banking and Finance, 29 (7) $1813-1834$.

Murdock, K. (2002). Intrinsic motivation and optimal incentive contracts. Rand Journal of Economics, 33 (4) 650 671.

Murphy, K. (1999). Executive compensation. Handbook of Labor Economics, First edition, 3 (Chapter 38) 2485 2563.

Murphy, K. and Sandino, T. (2010). Executive pay and "independent" compensation consultant. Journal of Accounting and Economics, 49 (3) 247-262.

Ozkan, N. (2007). Do corporate governance mechanisms influence CEO compensation? An empirical investigation of UK companies. Journal of Multinational Financial Management, 17 (5) 349-364.

Pagano, M. and Röell, A. (1998). The choice of stock ownership structure: agency costs, monitoring and the decision to go public. Quarterly Journal of Economics, 113 (1) 187-225.

$\mathrm{Su}, \mathrm{Z}$. Li, Y. and Li, L. (2011). Ownership concentration and executive compensation in emerging economies: Evidence from China. Corporate Governance, 10 (3) 223-233.

Zwiebel, J. (1995). Block investment and partial benefits of corporate control. Review of Economic Studies, 62 (3) 161-185. 


\section{APPENDIX}

Table 1. Variable Definitions And Data Sources

\begin{tabular}{|c|c|c|}
\hline Variables & Definition & Data Sources \\
\hline \multicolumn{3}{|l|}{ Managerial Compensation } \\
\hline $\begin{array}{l}\text { Total Compensation of CEO } \\
(\text { TotCeoComp) }\end{array}$ & $\begin{array}{l}\text { The natural logarithm of all components of the owner-manager } \\
\text { compensation (fixed salary, bonus, stock options, and granted stocks). }\end{array}$ & $\begin{array}{l}\text { Annual reports and } \\
\text { author's calculations }\end{array}$ \\
\hline $\begin{array}{l}\text { Variable compensation of } \\
\text { CEO (VarCeoComp) }\end{array}$ & $\begin{array}{l}\text { The natural logarithm of all variable components of the owner- } \\
\text { manager compensation (bonus, stock options, and granted stocks). }\end{array}$ & As above \\
\hline \multicolumn{3}{|l|}{ Ownership structure } \\
\hline $\begin{array}{l}\text { Excess of Control } \\
(\text { ExControl })^{*}\end{array}$ & $\begin{array}{l}\text { (UCO-UCF)/UCO if the firm is closely held, and zero otherwise, } \\
\text { where UCO: ultimate control rights of the owner-manager, and UCF: } \\
\text { ultimate cash flow rights of the owner-manager. }\end{array}$ & $\begin{array}{l}\text { Annual reports and } \\
\text { author's calculations }\end{array}$ \\
\hline $\begin{array}{l}\text { Multiple large shareholders } \\
(M L S D)\end{array}$ & $\begin{array}{l}\text { Dummy variable that takes the value of one if the firm has at least one } \\
\text { external blockholder that controls, directly or indirectly, at least } 10 \% \\
\text { of the voting rights of the firms, and zero otherwise. }\end{array}$ & As above \\
\hline \multicolumn{3}{|l|}{ Control Variables } \\
\hline Board size (BoardSize) & The natural logarithm of the number of the directors on the board. & $\begin{array}{l}\text { Annual reports and } \\
\text { author's calculations }\end{array}$ \\
\hline Duality (Duality) & $\begin{array}{l}\text { Dummy variable that equals one if the executive accumulates both the } \\
\text { titles of CEO and chairman of the board of directors, and zero } \\
\text { otherwise. }\end{array}$ & As above \\
\hline $\begin{array}{l}\text { Independent directors } \\
\text { (IndDir) }\end{array}$ & The proportion of independent directors on the board. & As above \\
\hline $\begin{array}{l}\text { Compensation committee } \\
\text { (CompCom) }\end{array}$ & $\begin{array}{l}\text { Dummy variable that equals one if the firm has a compensation } \\
\text { committee, and zero otherwise. }\end{array}$ & As above \\
\hline CEO's Age (CeoAge) & The natural logarithm of the CEO's age in years. & As above \\
\hline CEO's tenure (CeoTen) & $\begin{array}{l}\text { The natural logarithm of the number of years the CEO has been in the } \\
\text { position. }\end{array}$ & As above \\
\hline CEO founder (CeoFon) & $\begin{array}{l}\text { Dummy variable that takes the value of one if the current CEO is the } \\
\text { founder of the firm or a member of the founding family, and zero } \\
\text { otherwise. }\end{array}$ & As above \\
\hline Return on assets (ROA) & The ratio of earnings before interest and taxes to total assets. & Worldscope \\
\hline Firm size (FirmSize) & The natural logarithm of total assets. & As above \\
\hline
\end{tabular}

Table 2. Descriptive Statistics

\begin{tabular}{|c|c|c|c|c|c|c|c|c|}
\hline Variables & $\mathbf{N}$ & Mean & S.D & $\begin{array}{c}\text { 5th } \\
\text { percentile }\end{array}$ & $\begin{array}{c}\text { 25th } \\
\text { percentile }\end{array}$ & Median & $\begin{array}{c}\text { 75th } \\
\text { percentile }\end{array}$ & $\begin{array}{c}\text { 95th } \\
\text { percentile }\end{array}$ \\
\hline CeoTotComp $(€)$ & 1476 & 311,458 & 0,003 & 50,868 & 152,817 & 265,667 & 601,390 & 3194,688 \\
\hline CeoVarComp $(€)$ & 1476 & 3,980 & 0,200 & 0 & 0 & 29,990 & 180,773 & 2345,478 \\
\hline $\operatorname{ExCont}(\%)$ & 1476 & 19.680 & 25.141 & 0 & 0.220 & 17.094 & 31.071 & 60.400 \\
\hline $\begin{array}{l}\operatorname{MLSD}^{*}(\%) \\
(\mathrm{N}(\mathrm{MLSD}=1)=493)\end{array}$ & 1476 & 33.40 & 47.180 & 0 & 0 & 0 & 1 & 1 \\
\hline BoardSize & 1476 & 6.372 & 1.620 & 2.998 & 3.998 & 5.995 & 9.000 & 14.999 \\
\hline $\begin{array}{l}\text { Duality }{ }^{*}(\%) \\
\text { (N(Duality=1)=1022) }\end{array}$ & 1476 & 69.241 & 46.165 & 0 & 0 & 1 & 1 & 1 \\
\hline $\operatorname{IndDir}(\%)$ & 1476 & 27.406 & 24.521 & 0 & 0 & 28.571 & 50.000 & 66.600 \\
\hline $\begin{array}{l}\operatorname{CompCom}^{*}(\%) \\
(\mathrm{N}(\mathrm{CompCom}=1)=647)\end{array}$ & 1476 & 43.869 & 49.351 & 0 & 0 & 0 & 1 & 1 \\
\hline CeoAge(years) & 1476 & 52.457 & 1.184 & 38.978 & 46.997 & 52.995 & 58.997 & 67.829 \\
\hline CeoTen(years) & 1476 & 6.275 & 2.154 & 1.999 & 3.665 & 5.995 & 10.990 & 23.998 \\
\hline $\begin{array}{l}\text { CeoFon }{ }^{*}(\%) \\
(\mathrm{N}(\mathrm{CeoFon}=1)=694)\end{array}$ & 1476 & 47.018 & 49.927 & 0 & 0 & 0 & 1 & 1 \\
\hline $\mathrm{ROA}(\%)$ & 1476 & 4.370 & 9.330 & -11.8 & 2.345 & 4.807 & 8.016 & 15.300 \\
\hline FirmSize & 1476 & 12,392 & 2,162 & 9,480 & 10,819 & 12,027 & 13,669 & 13,778 \\
\hline
\end{tabular}

Notes: This table presents the statistics descriptive of all variables used in the study. All variables are defined in Table 1. Financial variables used are winsorized at the $1 \%$ and $99 \%$ levels. 
Table 3. Correlation Matrix

\begin{tabular}{|c|c|c|c|c|c|c|c|c|c|c|c|c|c|}
\hline & 1 & 2 & 3 & 4 & 5 & 6 & 7 & 8 & 9 & 10 & 11 & 12 & 13 \\
\hline $\begin{array}{l}\text { 1.TotCeo } \\
\text { Comp }\end{array}$ & 1.000 & & & & & & & & & & & & \\
\hline $\begin{array}{l}\text { 2. VarCeo } \\
\text { Comp }\end{array}$ & $0.5313^{\mathrm{a}}$ & 1.000 & & & & & & & & & & & \\
\hline 3.ExControl & 0.0360 & $0.0776^{\mathrm{a}}$ & 1.000 & & & & & & & & & & \\
\hline 4.MLSD & $-0.0922^{\mathrm{a}}$ & $-0.1295^{\mathrm{a}}$ & 0.0276 & 1.000 & & & & & & & & & \\
\hline 5.BoardSize & $0.4584^{\mathrm{a}}$ & $0.3901^{\mathrm{a}}$ & 0.0391 & $-0.0504^{\mathrm{c}}$ & 1.000 & & & & & & & & \\
\hline 6.Duality & $-0.0809^{\mathrm{a}}$ & $-0.0479^{\mathrm{c}}$ & 0.0079 & -0.0322 & $-0.1210^{\mathrm{a}}$ & 1.000 & & & & & & & \\
\hline 7.IndDir & $0.3292^{\mathrm{a}}$ & $0.2833^{\mathrm{a}}$ & 0.0065 & $-0.0767^{\mathrm{a}}$ & $0.4065^{\mathrm{a}}$ & $-0.2164^{\mathrm{a}}$ & 1.000 & & & & & & \\
\hline 8.CompCom & $0.4076^{\mathrm{a}}$ & $0.2932^{\mathrm{a}}$ & 0.0163 & $-0.0857^{\mathrm{a}}$ & $0.4313^{\mathrm{a}}$ & $-0.1336^{\mathrm{a}}$ & $0.4052^{\mathrm{a}}$ & 1.000 & & & & & \\
\hline 9.CeoAge & $0.1039^{\mathrm{a}}$ & 0.0375 & -0.0328 & $-0.0997^{\mathrm{a}}$ & $0.1946^{\mathrm{a}}$ & $0.0734^{\mathrm{a}}$ & 0.0248 & $0.0867^{\mathrm{a}}$ & 1.000 & & & & \\
\hline 10.CeoTen & 0.0112 & -0.0323 & -0.0092 & $-0.0608^{b}$ & $-0.0521^{b}$ & $0.2184^{\mathrm{a}}$ & -0.0244 & $-0.0437^{\mathrm{c}}$ & $0.2180^{\mathrm{a}}$ & 1.000 & & & \\
\hline 11.CeoFon & $-0.0326^{\mathrm{c}}$ & $-0.0589^{b}$ & 0.0122 & -0.0138 & $-0.1304^{\mathrm{a}}$ & $0.1102^{\mathrm{a}}$ & $-0.1237^{\mathrm{a}}$ & -0.0456 & -0.0004 & $0.0735^{\mathrm{a}}$ & 1.000 & & \\
\hline 12.ROA & $0.0791^{\mathrm{a}}$ & $0.0538^{\mathrm{b}}$ & $0.0499^{\mathrm{c}}$ & -0.0399 & $0.0496^{\mathrm{c}}$ & 0.0038 & -0.0305 & 0.0150 & 0.0289 & 0.0143 & $0.0740^{\mathrm{a}}$ & 1.000 & \\
\hline 13. FirmSize & $0.6462^{\mathrm{a}}$ & $0.4371^{\mathrm{a}}$ & 0.0159 & $-0.1655^{\mathrm{a}}$ & $0.6678^{\mathrm{a}}$ & $-0.0878^{a}$ & $0.3561^{\mathrm{a}}$ & $0.4232^{\mathrm{a}}$ & $0.2259^{\mathrm{a}}$ & -0.0308 & $-0.0971^{\mathrm{a}}$ & $0.1392^{\mathrm{a}}$ & 1.000 \\
\hline
\end{tabular}

Notes. This table presents Pearson correlation between variables used in the study. All variables are defined in Table 1. Financial variables are winsorized at the $1 \%$ and $99 \%$ levels. a, b and c denote statistical significance at the $1 \%, 5 \%$, and $10 \%$ levels, respectively.

Table 4. Regression Results

\begin{tabular}{|c|c|c|c|c|}
\hline \multirow[b]{2}{*}{ ExControl } & \multicolumn{2}{|c|}{$\begin{array}{c}\text { Dependent variable: } \\
\text { CeoTotComp } \\
\text { (Column 1) }\end{array}$} & \multicolumn{2}{|c|}{$\begin{array}{c}\text { Dependent variable: } \\
\text { CeoVarComp } \\
\text { (Column 2) }\end{array}$} \\
\hline & $\begin{array}{c}0.041 \\
(0.34)\end{array}$ & & $\begin{array}{c}1.218^{b} \\
(2.07)\end{array}$ & \\
\hline MLSD & & $\begin{array}{c}0,034 \\
(0,44)\end{array}$ & & $\begin{array}{c}0.782^{\mathrm{c}} \\
(-1.82)\end{array}$ \\
\hline BoardSize & $\begin{array}{r}0.037 \\
(0.29)\end{array}$ & $\begin{array}{c}0.27 \\
(0.033)\end{array}$ & $\begin{array}{c}2.68^{\mathrm{a}} \\
(1.434)\end{array}$ & $\begin{array}{c}2.96^{\mathrm{a}} \\
(1.579)\end{array}$ \\
\hline Duality & $\begin{array}{c}-0.024 \\
(-0.28) \\
\end{array}$ & $\begin{array}{c}-0.27 \\
(-0.023)\end{array}$ & $\begin{array}{c}0.88 \\
(0.369)\end{array}$ & $\begin{array}{c}0.84 \\
(0.351) \\
\end{array}$ \\
\hline IndDir & $\begin{array}{c}1.58 \\
(0.29)\end{array}$ & $\begin{array}{c}1.58 \\
(0.293)\end{array}$ & $\begin{array}{c}2.00^{\mathrm{b}} \\
(1.778)\end{array}$ & $\begin{array}{c}1.86^{\mathrm{c}} \\
(1.649)\end{array}$ \\
\hline CompCom & $\begin{array}{c}0.339^{\mathrm{a}} \\
(3.37)\end{array}$ & $\begin{array}{c}0.340^{\mathrm{a}} \\
(3.41)\end{array}$ & $\begin{array}{c}0.744 \\
(1.58)\end{array}$ & $\begin{array}{c}0.705 \\
(1.51)\end{array}$ \\
\hline CeoAge & $\begin{array}{c}-0.406 \\
(-1.58)\end{array}$ & $\begin{array}{c}-0.405 \\
(-1.57)\end{array}$ & $\begin{array}{c}-1.848 \\
(-1.39)\end{array}$ & $\begin{array}{c}-1.983 \\
(-1.51)\end{array}$ \\
\hline CeoTen & $\begin{array}{c}0.101^{\mathrm{b}} \\
(1.97)\end{array}$ & $\begin{array}{c}0.102^{b} \\
(1.98)\end{array}$ & $\begin{array}{c}-0.004 \\
(-0.02)\end{array}$ & $\begin{array}{c}-0.031 \\
(-0.12)\end{array}$ \\
\hline CeoFon & $\begin{array}{c}0.066 \\
(0.86) \\
\end{array}$ & $\begin{array}{c}0.067 \\
(0.87) \\
\end{array}$ & $\begin{array}{c}-0.155 \\
(-0.41) \\
\end{array}$ & $\begin{array}{r}-0.167 \\
(-0.45) \\
\end{array}$ \\
\hline ROA & $\begin{array}{c}-0.035 \\
(-0.01)\end{array}$ & $\begin{array}{c}0.004 \\
(0.01)\end{array}$ & $\begin{array}{c}-0.366 \\
(-0.25)\end{array}$ & $\begin{array}{c}-0.230 \\
(-0.15)\end{array}$ \\
\hline FirmSize & $\begin{array}{c}0.366^{\mathrm{a}} \\
(11.63) \\
\end{array}$ & $\begin{array}{c}0.367^{\mathrm{a}} \\
(11.58)\end{array}$ & $\begin{array}{c}0.755^{\mathrm{a}} \\
(6.33)\end{array}$ & $\begin{array}{c}0.724^{\mathrm{a}} \\
(5.96)\end{array}$ \\
\hline Year Dummies & Yes & Yes & Yes & Yes \\
\hline Industry Dummies & Yes & Yes & Yes & Yes \\
\hline Intercept & $\begin{array}{l}8.939^{\mathrm{a}} \\
(9.46)\end{array}$ & $\begin{array}{l}8.913^{\mathrm{a}} \\
(9.47)\end{array}$ & $\begin{array}{c}1.246 \\
(0.25)\end{array}$ & $\begin{array}{c}2.472 \\
(0.50)\end{array}$ \\
\hline Number of observations & 1476 & 1476 & 1476 & 1476 \\
\hline R-squared & $47.63 \%$ & $47.64 \%$ & $26.23 \%$ & $26.35 \%$ \\
\hline F-Value & 26.18 & 26.17 & 16.83 & 16.44 \\
\hline
\end{tabular}


NOTES 